\title{
DOKUMENTASI ETNOBOTANI-LINGUISTIK TUMBUHAN SAGU: LAPORAN AWAL DARI ETNIS MARORI DI TAMAN NASIONAL WASUR MERAUKE
}

\author{
La Hisa ${ }^{1}$, Agustinus Mahuze ${ }^{2}$ and I Wayan $\mathrm{Arka}^{3}$ * \\ ${ }^{1}$ Staf pada Balai Taman Nasional Wasur Merauke \\ ${ }^{2}$ Guru pada SMK Kesehatan Yaleka Maro Merauke \\ ${ }^{3}$ Australian National University/Universitas Udayana
}

\begin{abstract}
Abstrak
Makalah ini membahas dokumentasi etnobotani-linguistik tanaman sagu pada etnis Marori. Sagu adalah tanaman dengan nilai sosial budaya dan ekonomi yang tinggi pada masyarakat Papua umumnya dan untuk kelompok etnis Marori pada khususnya. Secara sosio-kultural, sagu memainkan peran sentral dalam kehidupan sehari-hari, karena sagu ini digunakan dalam berbagai ritual penting, sejak lahir hingga upacara pemakaman, yang melibatkan kewajiban dan tanggung jawab sosial tertentu. Sagu juga menjadi identitas klan Mahuze. Secara tradisional sagu memiliki nilai ekonomi yang tinggi pula, yakni sebagai makanan pokok. Namun, telah terjadi proses akulturasi dan perubahan yang meluas sehingga terjadi pergeseran antara lain pada pola konsumsi makanan pokok, dari sagu ke beras. Selain itu, bahasa Marori sangat terancam; pengetahuan asli setempat yang berkaitan dengan sagu (dan juga tanaman lainnya) juga semakin terancam punah. Hal ini terutama disebabkan oleh faktor sosio-historis-budaya eksternal yang telah mempengaruhi dan membentuk ekologi saat ini di Merauke. Peran bahasa sangat penting dalam transmisi pengetahuan lokal dari satu generasi ke generasi berikutnya. Oleh karena itu, upaya kolaborasi semua pemangku kepentingan sangat dibutuhkan untuk melakukan dokumentasi bahasa dan budaya, sebagai bagian dari pelestarian dan pelestarian bahasa dan budaya kelompok etnis ini. Diskusi mengenai etnolinguistik sagu dalam makalah ini membahas dua aspek yang terkait, yaitu aspek dokumentasi dan aspek etnobotani-linguistik. Taksonomi rakyat dan butir leksikal terkait dengan sagu dan pengolahannya menunjukkan kosakata yang kaya, yang terkait pengetahuan sosio-kultural sagu. Makalah ini juga membahas aspek sosio-kultural dan ekonomi sagu, yang menguraikan adanya larangan untuk perdagangan sagu, yang menjadi masalah dalam usaha memaksimalkan potensi ekonomi sagu, dan upaya yang telah dilakukan untuk mengatasi masalah ini oleh pemangku kepentingan terkait.
\end{abstract}

Kata kunci: etnobotani, sagu, dokumentasi bahasa, taksonomi rakyat, keterancaman bahasa, kontak bahasa

\begin{abstract}
This paper discusses the ethnobotanical-linguistic documentation of sago (sago Metroxylon Rottb.) in Marori. Sago is a plant of high socio-cultural and economic values for the Papuan people in general and for the Marori ethnic group in particular. Socio-culturally, sago plays a central role in everyday life: it is used in a variety of important rituals, from birth to funeral ceremonies, which involve certain social obligation and responsibility. It is the identity of the Mahuze clan. Traditionally sago has a high economic value too, as staple food. However, there has been a widespread process of acculturation and change resulting in a shift, among other things, in the consumption patterns of staple food, from sago to rice. In addition, the Marori language
\end{abstract}


is highly endangered; the local indigenous knowledge related to sago (and also other plants) is also increasingly endangered. This is mainly due to external socio-historicalcultural factors that have affected and shaped the current ecology in Merauke and in modern Indonesia. The role of language is central in the intergenerational transmission of indigenous knowledge. Collaborative efforts of all stakeholders are therefore urgently needed to do language and cultural documentation, as part of the conservation and preservation of language and culture of this ethnic group. The discussion on the entholinguistics of sago in this paper addresses two related aspects, namely documentation aspects and ethnobotanical-linguistic aspects. The discussion on the folk taxonomy and lexical items in relation to sago plants and sago processing highlights rich vocabulary related to socio-cultural knowledge of sago. The paper also discusses the socio-cultural and economic significance of sago, outlining a sago-trading taboo posing a delicate problem in maximizing the economic potential of sago, and the efforts so far done to address the issues by relevant stakeholders.

Keywords: ethnobotany, sago, language documentation, folk taxonomy, language endangerment, language contact

\section{PENDAHULUAN}

Sagu di wilayah Merauke memiliki potensi yang sangat besar apabila dibandingkan dengan daerah-daerah lain di Papua. Djoefrie (2014) mengemukakan bahwa hutan sagu di wilayah Merauke merupakan yang terluas di Papua, yakni seluas 1.232.151 hektar atau sekitar 25,9\% dari luas keseluruhan hutan sagu di Papua, yang mencapai 4.749.325 hektar; lihat Peta 1 dan Diagram 1. Meskipun secara spesifik belum ada data-data yang mengemukakan seberapa luas hutan sagu di wilayah adat etnis Marori di Taman Nasional Wasur, potensi (ekonomis) sagu yang ada di hutan-hutan kemungkinan cukup tinggi mengingat sebagian besar hutan adat merupakan daerah dataran rendah yang didominasi oleh rawa-rawa yang sangat sesuai bagi pertumbuhan tegakan sagu. Tegakan sagu juga dapat dijumpai dengan mudah di rawa-rawa sekitar pemukiman.

Sagu memiliki peran sentral dalam perspektif kehidupan sosial budaya baik pada etnis Marori maupun etnis lainnya di Indonesia (Timur). Peran sentral ini terkait dengan peran kombinasi sagu sebagai sumber makanan dan juga pernannya dalam sejumlah kegunaan lain (Balick 1988). Misalnya, daunnya secara tradisional digunakan untuk atap rumah, tembok penyekat rumah, dan keranjangan anyaman; batang pohonnya yang keras sebagai pengganti kayu; dan tentu isi sagunya sendiri untuk sumber makanan utama. Karena perannya yang multiguna itu, sago dikatakan sebagai spesies etnobiologis yang sangat fundamental (ethnobiological keystone species) (Ellen 2006). Kini, di Indonesia, telah terbentuk masyarakat sagu Indonesia (http://www.massi.id/index.php/organization) yang tujuannya adalah untuk meninggkatkan kesadaran masyarakat dan mempromosikan peran dan manfaat multiguna sagu, khususnya nilai ekonomisnya sehingga kita, masyarakat lokal, tidak terlalu bergantung pada beras.

Pada suku Marori sagu memang memegang peran sentral dalam berbagai ritual-ritual penting, mulai dari kelahiran sampai kematian. Sagu merupakan salah satu kelengkapan yang harus dipenuhi dan menjadi kewajiban dan tanggung jawab sosial bagi yang menyelenggarakan ritual tersebut. Selain untuk kepentingan ritual semata, sagu di hutan-hutan adat etnis Marori tentunya pada masa yang akan datang dapat diarahkan untuk pengembangan ekonomi rakyat 
tanpa mengesampingkan kearifan lokal dan nilai sakralitas sagu itu sendiri sebagai lambang klen Mahuze dalam sistem totemisme Marori.

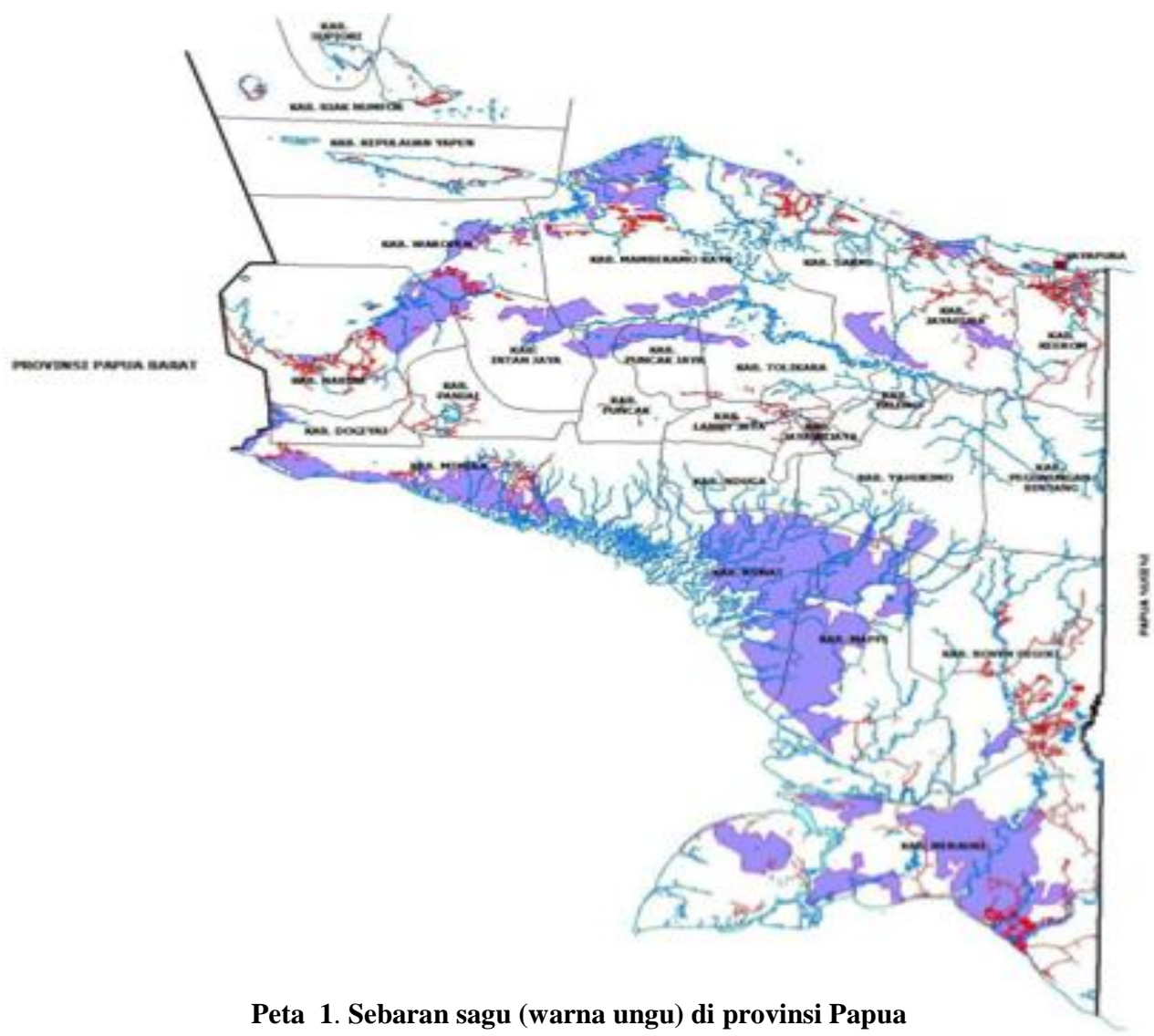

(Djoefrie dkk. 2014)

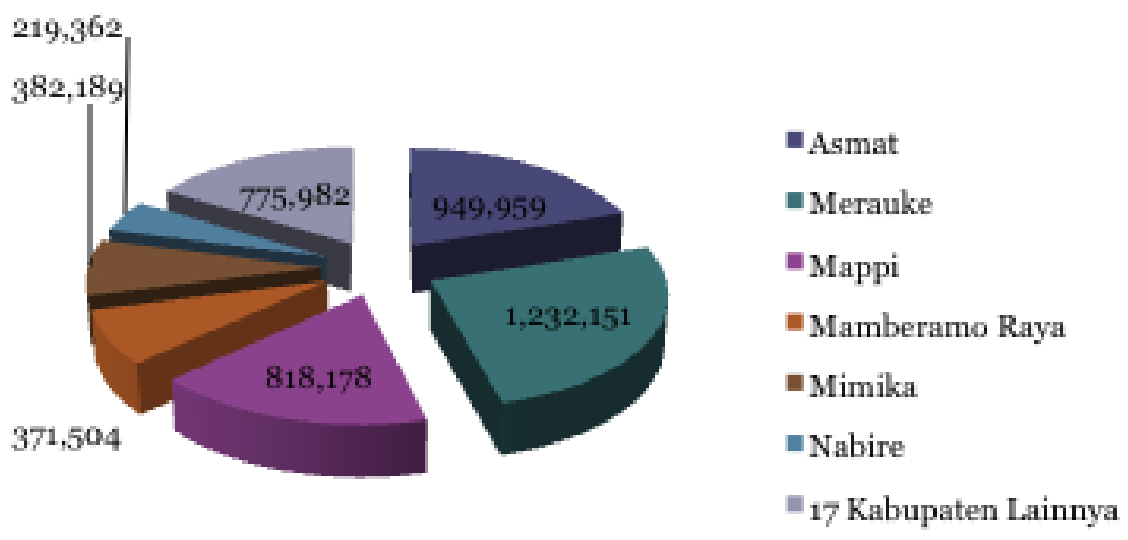

Diagram 1 Luas wilayah sagu di provinsi Papua (dalam hektar)

(Djoefrie dkk. 2014)

Tantangan yang harus dihadapi saat ini adalah perubahan pola hidup sebagai konsekuensi dari bergulirnya waktu yang membawa budaya-budaya baru dari luar etnis Marori ke dalamnya. Misalnya, pola konsumsi di hampir semua suku di Papua dari semula mengkonsumsi sagu beralih ke beras. Dengan perubahan ini maka pengetahuan tentang sagu, pengetahuan tentang jenisnya dalam taksonomi rakyat maupun pengetahuan cara budidaya dan 
pengolahannya semakin rendah di kalangan generasi muda. Hal ini akan menjadi salah satu faktor kurangnya perhatian untuk melestarikan tegakan sagu sehingga luas hutan sagu akan menyusut dan berubah menjadi lahan tidak produktif baik dari segi ekonomi maupun ekologi. Akibatnya, pangan dari sagu semakin terpinggirkan. Dalam konteks pengelolaan Taman Nasional Wasur yang dikelola dengan sistem zonasi, berkurangnya luas hutan sagu akan sama halnya dengan perubahan vegetasi dan perubahan zona religi/budaya/sejarah sebagai tempattempat penting masyarakat lokal yang dilindungi.

Selain membawa perubahan pada pola konsumsi pangan, akulturasi budaya-budaya dari luar juga membawa bahasa Marori pada tingkat keterancaman yang tinggi, sehingga pengetahuan-pengetahuan tentang sagu dan tumbuh-tumbuhan lainnya yang dibungkus dengan bahasa sebagai media transmisinya menjadi terancam punah. Hal ini menjadi faktor-faktor eksternal sosiokultural yang mempengaruhi dan membentuk ekologi budaya yang saat ini terjadi pada etnis Marori di Merauke. Oleh karena itu, bahasa memiliki peran sentral dalam mentransmisikan pengetahuan-pengetahuan lokal yang dimiliki komunitas atau etnis tertentu. Seiring dengan laju kepunahan budaya, bahasa dan pengetahuan-pengetahuan lokal maka kepedulian untuk meneliti dan mendokumentasikan etnobotani dan linguistik khususnya terkait tumbuhan sagu sebagai salah satu upaya konservasinya perlu untuk dilakukan.

Makalah ini bertujuan untuk membahas tentang pengetahuan dan pemanfaatan sagu oleh etnis Marori di Taman Nasional Wasur berdasarkan temuan awal dan pengalaman dalam kegiatan dokumentasi etnobotani-linguistik di suku Marori, Kabupaten Merauke Papua. Masalah etnobotani-linguistik sagu diangkat menjadi fokus di dalam makalah ini karena mengingat begitu pentingnya tumbuhan ini dalam kehidupan sosiokultural dan juga ekonomi masyarakat tradisional di Papua dan khususnya di etnis Marori di Merauke. Setidak-tidaknya ada dua butir isu utama yang saling terkait yang digarisbawahi dan akan dibahas lebih lanjut dalam tulisan ini: (i) kontak budaya dan bahasa dan proses akulturasi nilai-nilai, perubahan ekologi dan pola hidup, khususnya terkait dengan peralihan konsumsi dan penggunaan sagu sebagai pangan utama; dan (ii) pendokumentasian sago dan pengetahuan lokal terkait.

\section{METODOLOGI}

Metodologi yang digunakan di dalam penelitian ini adalah pengambilan data melalui wawancara, eksplorasi lapangan dan juga teknik-teknik dokumentasi bahasa (Dwyer, 2006; Himmelmann, 1998; Martin, 1995 dan Albuquerque et al., 2014). Dokumentasi etnobotani yang dilakukan merupakan bagian dari dokumentasi etnobiologi yang didukung dana hibah ELDP (2016-17) mencakup dokumentasi bahasa dan pengetahuan etnobiologi umum. Data etnobotani sagu didapatkan dari hasil wawancara dengan beberapa narasumber, khususnya tokoh adat dan tetua dari klen Mahuze yang memahami lebih mendalam tentang sagu dan pemanfaatannya dalam etnis Marori. Selanjutnya, data dianalisis secara kualitatif, kemudian disajikan dalam bentuk uraian dan gambar-gambar.

\section{HASIL DAN PEMBAHASAN}

Sebelum membahas temuan dokumentasi etnobiologi sagu dan aspek lain yang terkait, di bawah ini akan diuraikan terlebih dahulu secara singkat konteks sosio-historis sagu, dan kontak budaya yang menyebabkan perubahan sosio-kulutal dan linguistis di Merauke. 


\section{Kontak bahasa-budaya dan aspek sosio-historis sagu}

Sagu (Metroxylon sagu) dewasa ditemukan tersebar dari wilayah Asia Tenggara daratan (Muangthai selatan dan Burma), semenajung Malaysia, wilayah kepulauan Indonesia, Filipina selatan dan pulau-pulau di sekitar Papua dan Nugini, sampai ke timur di kepulaian Solomon (Ellen 2006). Walaupun ada perdebatan dari mana sesungguhnya daerah asal asli sagu, apakah Maluku (Beccary 1981), atau Nugini (Barrau 1959, Flach 1997), tetapi ada kesepakatan bahwa genus and spesies of (Metrixylon) berasal dan berkembang asalnya di daerah Sahul (yakni daerah sekitar Seram); dan dari situ lalu menyebar ke barat melewati garis Wallace (Ellen 2006). Singkatnya, sagu adalah tanaman asli wilayah Indonesia Timur, yang sudah ada sejak ribuan tahun yang lampau.

Walaupun sagu adalah tanaman lokal yang mempunyai peran penting secara budaya, telah terjadi pergeseran akibat kontak budaya dan kontak ekonomi yang intens karena faktor migrasi non-Papua ke Papua, khususnya dalam tiga dekade terakhir di Merauke. Kontak yang demikian telah membawa perubahan ekologi fisik dan sosial-linguistis yang signifikan. Tidak hanya di di Merauke, tetapi sudah ada laporan penelitian yang menunjukkan bahwa terbukanya isolasi daerah yang dibarengi dengan derasnya migrasi dan meningkatnya kontak dengan etnis luar telah terbukti berakibat negatif atas keberlangsungan budaya dan bahasa lokal, yang dalam hal tertentu dapat menyebabkan punahnya bahasa dan budaya asli-lokal; misalnya kasus budaya/bahasa Ugong di Muangthai selatan (Bradley 1989). Tidak bisa dipungkiri, kehadiran transmigran dalam jumlah besar di Merauke dan daerah sekitarnya sampai wilayah dekat perbatasan dengan Papua Nugini, baik yang datang lewat program transmigrasi resmi pemerintah (dahulu), maupun yang datang atas prakarsa sendiri (belakangan), telah mengubah keseimbangan ekologi fisik-sosial-linguistis lokal khususnya di Merauke. Pembukaan hutan untuk kebutuhan pemukiman dan juga untuk kepentingan pembangunan ekonomi telah menimbulkan berbagai masalah, tidak hanya perubahan ekologi fisik (misalnya hilangnya kekayaan dan keragaman habitat, flora-fauna asli) tetapi juga masalah sosial seperti sengketakonflik horizontal antar klan dan juga antar orang lokal and non-lokal. Misalnya, cocok tanam padi dan konsumsi nasi semakin meningkat, dan program MIFEE (Merauke Integrated Food and Energi Estate, https://awasmifee.potager.org/?page_id=57) diharapkan akan menjadikan Merauke sebagai lumbung padi/beras yang tidak hanya mencukupi kebutuhan lokal tetapi juga bisa ekspor keluar. Program ini bersama dengan pembukaan hutan untuk perkebunan sawit sangat kontroversial, karena kerusakan ekologis yang diakibatkan, dan manfaatnya tidak selalu langsung bisa dirasakan oleh masyarakat lokal. Terkait dengan pemertahanan sagu, pola konsumsi nasi, dan pengembangan lahan sawah, yang terjadi di masyarakat Marori dan wilayah sekitarnya adalah semakin hilangnya keberlangsungan pemeliharaan pohon sagu, dan semakin bergantungnya masyarakat pada nasi sebagai makanan utama sehari-hari. Gambar 1 and Gambar 2 memperlihatkan kontras dua situasi, kebun sagu yang tidak terpelihara dan persawahan yang apik.

Efek migrasi dan kontak budaya, misalnya, terlihat nyata di kampung Wasur tempat suku Marori bermukim. Kampung ini sekarang sudah multietnis, kini tidak hanya dihuni orang Marori tetapi juga ada penduduk etnis luar, baik dari etnis lain di Papua, maupun orang luar Papua seperti orang Jawa dan Maluku. Wasur II, kampung di sebelahnya, bahkan hampir tidak ada orang Marori. Kampung Wasur II didominasi oleh etnis Jawa. Akibat nyata dari migrasi dan kontak budaya/bahasa ini adalah tergusurnya bahasa lokal dari ranah komunikasi sehari-hari. Bahasa yang dipakai sehari-hari untuk komunikasi antargenerasi di Wasur sudah bukan lagi 
bahasa daerah Marori, tetapi bahasa Indonesia. Pemakaian bahasa Marori kini sangat terbatas, hanya dipakai oleh para tetua jika mereka berkomunikasi sesama tetua, atau dalam konteks tradisional ritual saja. Bahkan di Kampung Nalkin (wilayah suku Yei), di daerah perbatasan dengan Papua Nugini, proporsi penduduk orang Jawa di kampung itu telah sedemikian dominan sehingga telah menyebabkan anak-anak orang lokal menguasai bahasa Jawa sejak kecil. Situasi ini tentulah bukan ekologi yang sehat untuk keberlangsungan hidup bahasa lokal.

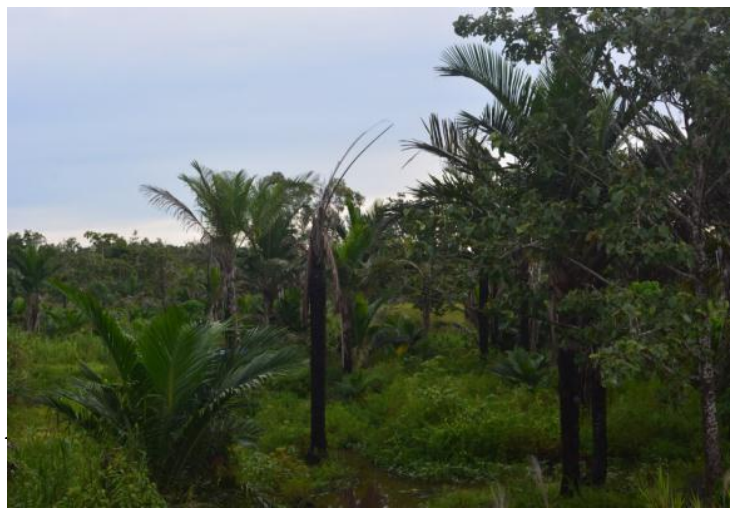

Gambar 2 Kebun sagu di sekitar kampung Wasur, Merauke

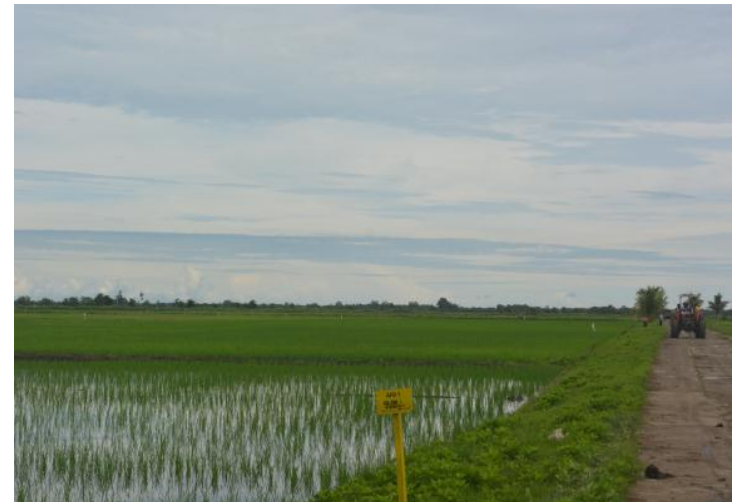

Gambar 1. Sawah yang terpelihara apik di sekitar kampung Wasur, Merauke

Meningkatnya kontak dengan budaya-bahasa luar berdampak pada semakin derasnya efek negatif dari perubahan ekologi yang menopang budaya-bahasa, khususnya untuk etnis minoritas seperti etnis Marori. Bahasa-budaya Marori sangat terancam punah; telah terjadi penggerusan penggunaan bahasa yang sangat signifikan, seperti yang diuraikan di atas. Karena bahasa adalah wahana pembungkus untuk transmisi berbagai informasi budaya dan pengetahuan lokal, maka kepunahannya juga berarti kepunahan pengetahuan budaya lokal itu sendiri. Ini terjadi pada ranah budaya lokal penting seperti terancam punahnya aneka pengetahuan lokal terkait dengan tumbuhan sagu. Hal ini mendorong keprihatinan berbagai pihak atau berbagai pemangku kepentingan untuk melakukan suatu aksi nyata untuk pemertahanan pengetahuan lokal dan produk-produk budaya yang lebih luas. Dokumentasi etnobotani-linguistik adalah salah satu langkah yang diambil dan di dalamnya melibatkan berbagai disiplin ilmu yang saling terkait yaitu linguistik, antropologi, biologi, botani, dan kehutanan. Prinsip kajian dan dokumentasi ini dilakukan secara partisipatif. Tokoh-tokoh masyarakat sebagai narasumber kunci terlibat secara penuh untuk mengidentifikasi pengetahuan tentang sagu secara tradisional.

Data yang digali dalam kajian ini, lebih khusus tentang etnobotani sagu, mencakup penamaan sagu (dalam nama Latin, Indonesia dan nama lokal Marori), taksonomi rakyat yang berlaku untuk jenis-jenis sagu yang ada dan peran penting sagu dalam sosiokultural. Selain aspek etnobotaninya, linguistik juga menjadi aspek penting untuk dikaji karena di dalamnya dikaji penyebutan sagu, bagian-bagiannya serta kegunaannya masing-masing dalam bahasa Marori.

Penelitian pengetahuan lokal tentang sagu yang cukup komprehensif dan mendalam di wilayah timur Indonesia sebelumnya dilakukan oleh Ellen (2006) di Seram, Maluku. Di sana sagu disebut secara umum dengan istilah hatane, sedangkan variasi jenisnya memiliki sebutan sendiri-sendiri dalam kategori klasifikasi rakyat. Adapun penyebutan sagu secara umum dan pengklasifikasian secara tradisional di etnis Marori akan diberikan pada bagian berikut sebagai 
temuan awal kami selama melakukan kajian dokumentasi bahasa dan etnobiologi secara umum yang saat ini masih berlangsung.
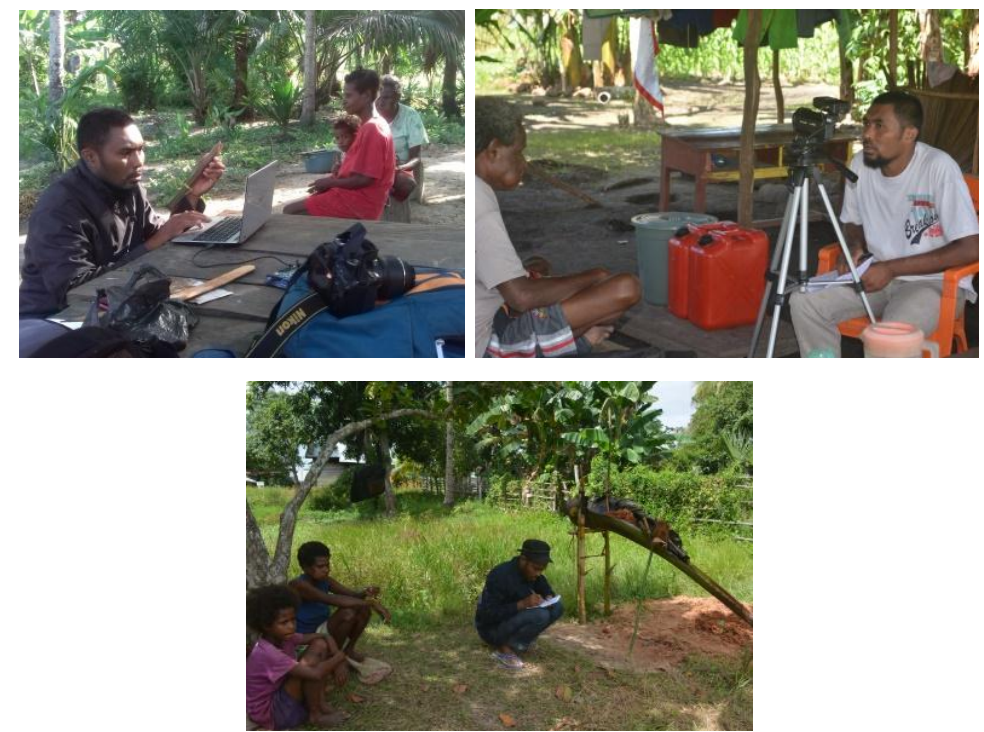

Gambar 3. Dari kiri ke kanan: kegiatan wawancara; dokumentasi; pengamatan dan pengambilan data di tempat pengolahan sagu tradisional.

\section{Taksonomi rakyat dan etnolinguistik sagu di suku Marori}

Sistem klasifikasi makhluk hidup baik tumbuhan maupun satwa dikenal ada dua, yakni sistem klasifikasi formal dan sistem klasifikasi rakyat. Kedua sistem ini merupakan alat untuk memudahkan manusia dalam mengelompokkan, mendeskripsikan, dan memberi nama makhluk hidup. Iskandar (2012) menjelaskan bahwa sistem klasifikasi rakyat dikenal pula dengan folk taxonomies yaitu sistem penamaan yang menggunakan nama daerah atau nama lokal sesuai dengan bahasa yang digunakan dalam masyarakat.

Pada bagian ini akan dipaparkan tentang bagimana masyarakat etnis Marori mengklasifikasikan tumbuhan sagu dengan penyebutannya dalam bahasa setempat berdasarkan karakteristik masing-masing jenis sagu. Nggi adalah sebutan umum untuk semua jenis sagu yang terdapat di wilayah adat Marori. Kemampuan masyarakat dalam melihat karakteristik morfologis sagu menghasilkan perbedaan-perbedaan yang sebenarnya samar tetapi hal ini menjadi dasar bagi mereka untuk membedakan variasi jenis yang ada. Temuan dalam penelitian ini menunjukkan adanya sistem klasifikasi rakyat yang berlaku terhadap tumbuhan sagu. Di dalam sistem klasifikasi rakyat ini terdapat tingkatan atau hirarkhi yang pada dasarnya menyerupai sistem klasifikasi formal (lihat diagram pada Gambar 4) (Berlin, 1992 dalam Escalada and Heong, 2016).

Lebih lanjut di dalam Escalada and Heong (2016) dijabarkan bahwa dalam taksonomi rakyat terdapat tiga tataran klasifikasi yang umum dipakai dan ini juga kami temukan dalam sistem klasifikasi sagu yang berlaku di etnis Marori yaitu:

1. Klasifikasi berdasarkan bentuk hidup

Sagu diklasifikasikan dengan mengacu pada bentuk dan karakterisitik umum tumbuhtumbuhan (ada pohon, semak, herba, rumput, dan lain-lain), sehingga pada tataran ini sagu dikategorikan sebagai $k w i=$ pohon. 
2. Klasifikasi berdasarkan sebutan umum

Tataran ini merupakan tingkatan spesies dalam klasifikasi biologi formal (misalnya: anjing dan kelapa) tetapi dalam taksonomi rakyat, tataran ini diposisikan sebagai umum sehingga dalam klasifikasi sagu yang berlaku di masyarakat Marori pun demikian. Dalam hal ini, sagu disebut nggi.

3. Klasifikasi berdasarkan sebutan yang spesifik.

Secara spesifik, masyarakat etnis Marori mengenal nggi ke dalam empat forma berdasarkan pengalaman mereka atas karakteristik yang dimiliki oleh setiap formanya. Forma-forma itu adalah elitel nggi, buov nggi, uliba nggi dan yuk nggi. Dalam klasifikasi formal, tataran ini seharusnya berada pada subspesies, sedangkan dalam klasifikasi rakyat yang berlaku di Marori secara spesifik dapat dikenal sebagai spesies. Meskipun perlu penelitian lebih lanjut, forma-forma yang dikenal di masyarakat ini kemungkinan merupakan forma-forma yang pernah diidentifikasi oleh Rauwerdink (1986) dalam Flach (1997). Rauwerdink mengidentifikasi berdasarkan perbedaanperbedaan morofologis yang dimiliki setiap forma.

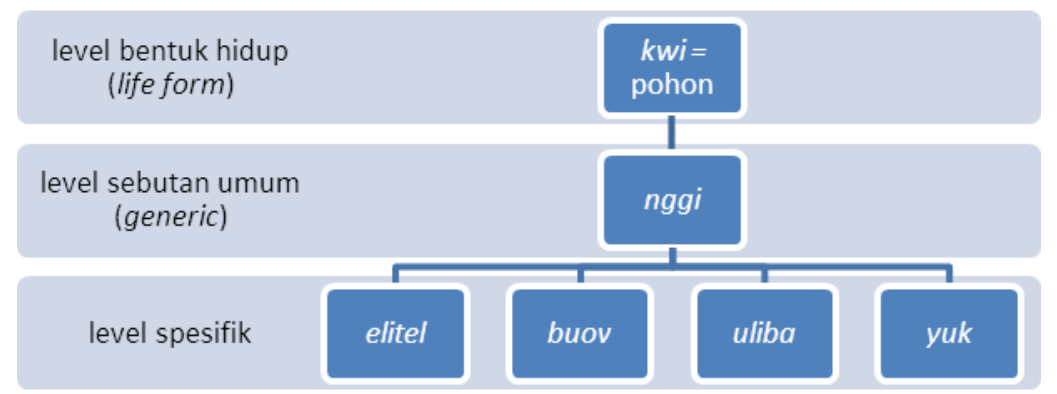

Gambar 4. Klasifikasi rakyat tumbuhan sagu yang dikenal di etnis Marori

Secara morfologis, keempat jenis sagu yang dikenal berdasarkan pengetahuan masyarakat Marori dapat dibedakan satu sama lain. Masyarakat membedakannya secara spesifik pada bagian daunnya yakni:

1. Elitel: memiliki daun panjang tetapi sempit

2. Buov: daun pendek tetapi permukaannya lebar

3. Uliba: daun agak panjang, tetapi permukaan di bawah daun berwarna keputih-putihan dan permukaan di atasnya hijau cerah, ada duri-duri kecil di tepi daun dan anakan memiliki duri-duri di tangkai sampai pelepah daun

4. Yuk: ujung daun runcing (forma yang lainnya tidak begitu runcing).

\section{Pentingnya sagu secara sosiokultural pada etnis Marori}

Sagu dalam ekologi budaya Marori memiliki peran sentral yang sangat penting baik dalam segi sosial budaya maupun ekonomi. Bagian-bagian tumbuhan sagu memiliki kegunaan sebagai bahan dan peralatan dalam proses pemanenan sampai menghasilkan tepung sagu. Selain menggambarkan nilai manfaat dari tumbuhan sagu, hal ini juga menggambarkan kekayaan kosakata dalam bahasa Marori terkait dengan tumbuhan sagu karena setiap alat memiliki sebutan sendiri-sendiri dalam bahasa lokal, yaitu: kosanggod, apuan, dapaa, roon, pondu, pendu, bing dan pendol. Kosanggod dan apuan terbuat dari bahan yang sama, dari pelepah daun sagu, tetapi penyebutannya setiap alat berbeda karena memiliki kegunaan yang berbeda. Dapa, 
bagian terluar dari batang sagu yang keras dan dibuat sedemikian rupa sebagai pasak untuk mengeratkan sambungan antara kosanggod dan apuan. Roon, pelepah sagu yang dipotong setinggi dada dan ditancapkan sebagai tiang penyangga kosanggod dan apuan. Pondu, anyaman daun sagu yang dipasang pada sisi kiri dan kanan apuan dan berfungsi sebagai penahan ampas empulur sehingga tidak terhempas ke luar ketika dihancurkan dengan tongkat pemukul. Pendu, anyaman daun sagu muda sebagai penyaring ampas sagu yang dipasang pada bagian ujung apuan. Bing, pelepah sampai tangkai daun yang diletakkan pada bagian bawah apuan sebagai saluran air yang mengandung pati sagu menuju wadah penampungan akhir. Pendol, potongan tangkai daun yang masih muda sebagai penahan bukaan wadah penampungan pati sagu. Bagianbagian alat pemanenan dan pengolahan sagu ditampilkan pada Gambar 5 berikut.

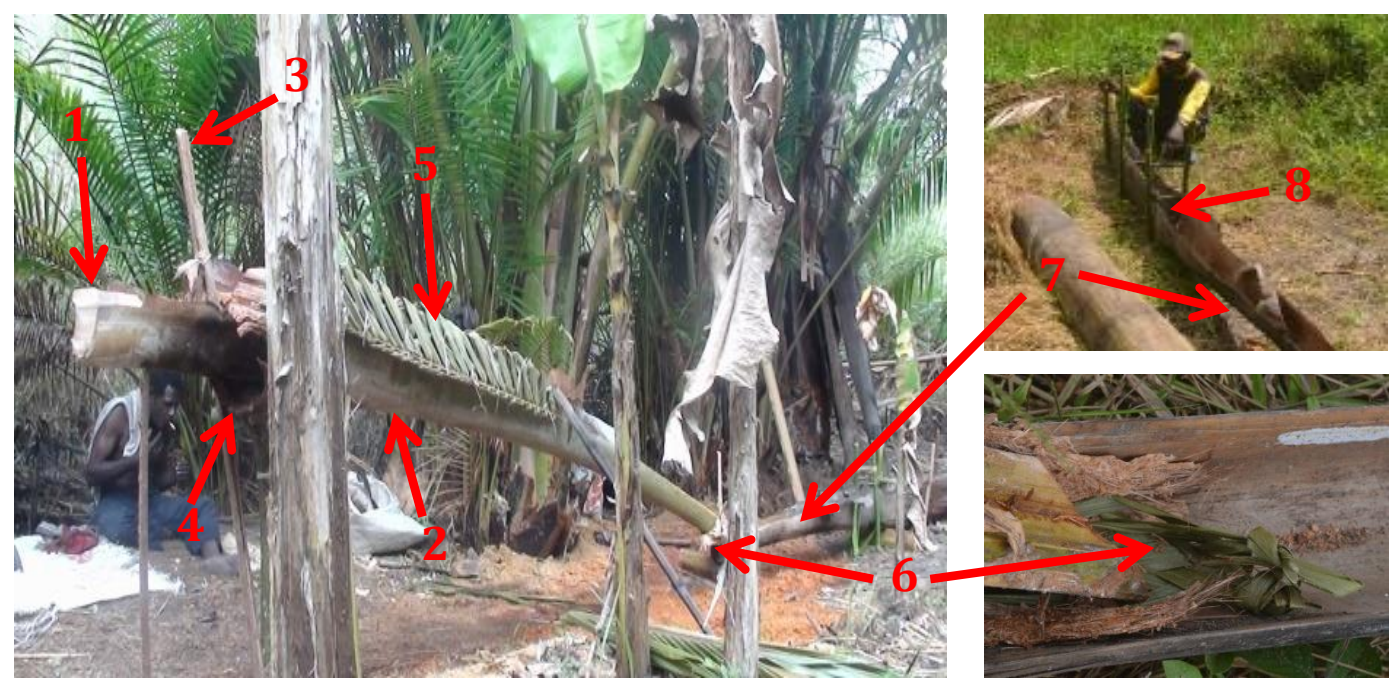

Gambar 5. Alat-alat pengolahan sagu : 1. Kosanggod; 2. Apuan; 3. Dapaa; 4. Roon; 5. Pondu; 6. Pendu; 7. Bing; dan 8. Pendol

Bukti pentingnya sagu pada etnis Marori secara sosiokultural bisa dilihat dengan keberadaan penamaan yang rinci terkait dengan sagu ini. Hal ini sesuai dengan hipotesis SapirWhorf yang menyatakan bahwa pembedaan yang rinci lewat bahasa atas benda-benda sekeliling suatu penutur bahasa memungkinkan penuturnya dan budaya penuturnya untuk melihat dan memberikan makna penting pada bagian-bagian budayanya secara lebih jelas. Selain adanya berbagai istilah terkait dengan alat-alat pengolahan sagu seperti diuraikan pada Gambar 5 di atas, pohon sagu itu sendiri ada berbagai macam (Gambar 4). Lebih lanjut, bagian-bagian pohon juga ada penamaan yang rinci; misalnya, seperti terlihat di Gambar 6, bahasa Marori mempunyai istilah-istilah rinci pada bagian daun, pelepah dan bunga pohon sagu. Ini terkait dengan tingginya penggunaan dan nilai kultural dari bagian-bagian pohon sagu ini pada etnis Marori.

Dilihat dari sejarahnya, sagu yang dikenal oleh Marori sebagai nggi itu merupakan tumbuhan penghasil pangan yang tertua bagi manusia (Ave, 1977). Etnis Marori telah memanfaatkannya sebagai sumber pangan pokok sejak dahulu kala meskipun pada saat ini sebagian dari mereka mulai mengkonsumsi beras. Berdasarkan penuturan dari narasumber kami, makanan yang berbahan dasar sagu diolah dengan cara pembakaran yang dikenal dengan istilah sief. Pemanfaatan sagu ini dapat dikembangkan kembali untuk meningkatkan ketahanan pangan berbasis sumber daya lokal karena mengingat saat ini tantangan pertanian untuk menghasilkan 
beras semakin kompleks di tengah isu perubahan iklim. Pengembangan komoditi sagu tidak hanya untuk mencukupi ketahanan pangan tetapi secara ekonomis dapat meningkatkan pendapatan masyarakat. Isu potensi ekonomis sagu ini, setidak-tidaknya di etnis Marori ada kendala karena nilai budayanya yang tinggi ini menyebabkan tanaman ini tabu untuk dikomersialkan sebagai komoditi dalam konteks pasar modern.
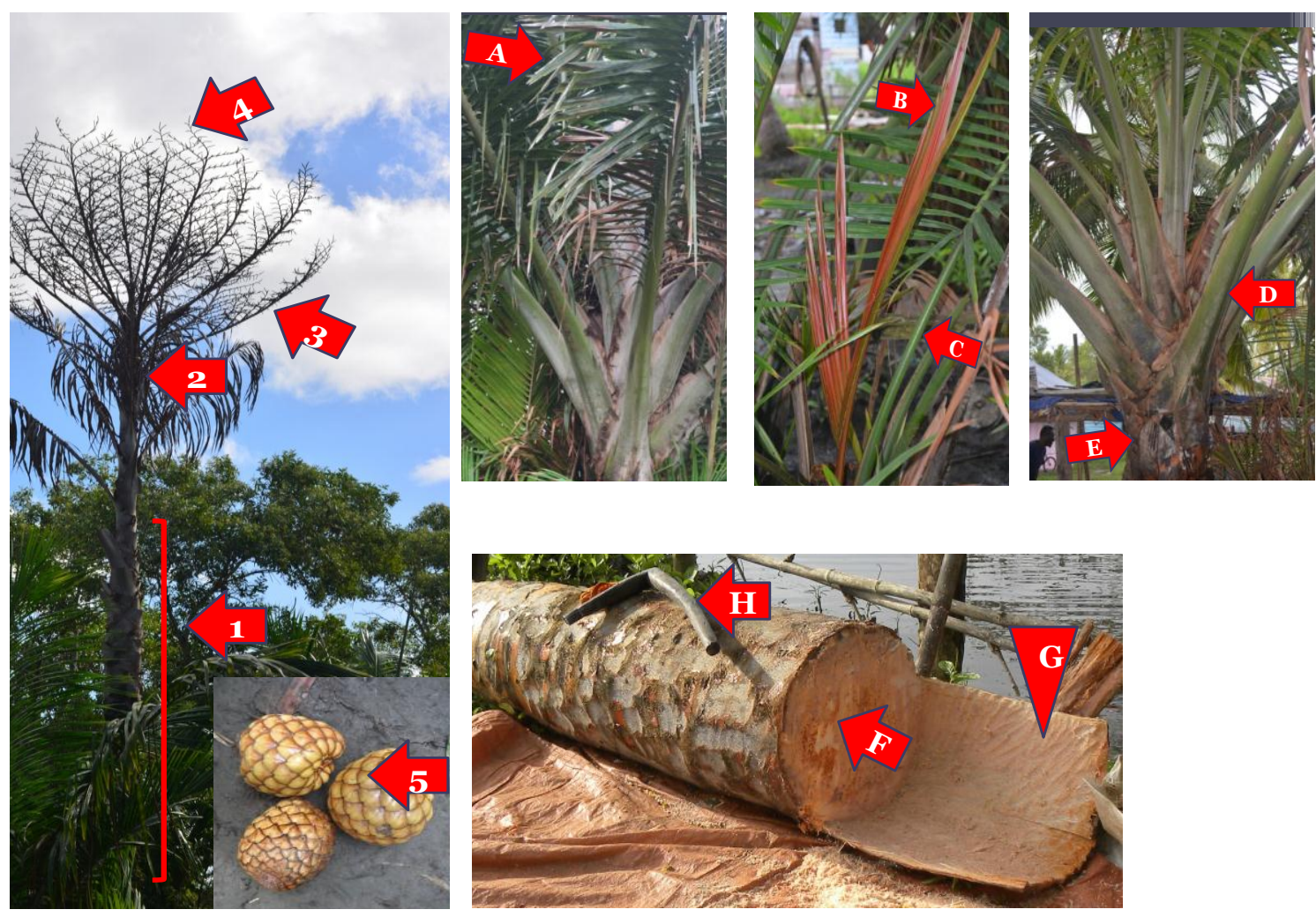

Gambar 6. Nama bagian pohon sagu: 1. Bend 'batang pokok', 2. Piyeu 'tangkai primer perbungaan', 3. Korou 'tangkai sekunder perbungaan, 4. Titin 'tangkai tersier perbungaan', 5. Buah sagu; A. Soru 'anak-anak daun', B. miyangga 'pucuk daun', C. yales 'tangkai daun pada tanaman muda', D. bing 'pelepah daun', E. mam 'sisa pelepah daun kering/yang telah gugur'.

Dari segi spiritualitas, sagu juga memiliki peran sentral dalam berbagai ritual. Segala ritual yang dilakukan di kalangan etnis Marori tidak pernah dipisahkan dengan ketersediaan tepung sagu sebagai persembahan maupun sebagai hidangan pokok untuk kesempurnaan ritual. Ritualritual yang berhubungan dengan produk sagu yakni: lamaran, kelahiran, tindik telinga, kematian, buka sar, ${ }^{1}$ penjemputan tamu, dan ritual-ritual lainnya. Adapun dalam kosmologi kehidupan orang Marori, sagu diposisikan sebagai simbol totem, yaitu sesuatu yang berhubungan dengan suatu dema tertentu dan dengan klen-klen tertentu. ${ }^{2}$ Dalam hal ini, nggi adalah simbol totem dari klen Mahuze tetapi pemanfaatannya dapat dilakukan oleh semua klen dengan seizin dari pemilik totem.

Satu catatan dari penelitian sagu ini bahwa dari empat jenis sagu yang dikenal oleh masyarakat, terdapat satu jenis yang dianggap langka secara lokal yakni yuk. Berbagai alasan dikemukakan terkait dengan kelangkaan jenis sagu ini, di antaranya karena sebuah alasan klasik yaitu pemanenan harus menunggu pohon berbunga terlebih dahulu, sifat produksi tepungnya yang sangat rendah dan juga menurut keyakinan mereka bahwa pengolahan jenis ini hanya 
dapat dilakukan oleh kaum perempuan tertentu saja. Oleh karena itu, jenis ini jarang ditanam dan populasi di kebun dan di dusun-dusun seringkali diabaikan pemeliharaannya sehingga pertumbuhannya tidak optimal dan sering dilanda kebakaran.

\section{Peluang dan tantangan pengembangan ekonomi sagu}

Sagu memiliki potensi yang cukup besar di hutan-hutan adat etnis Marori karena kondisi lingkungan tumbuh yang sangat memadai, yakni didominasi oleh rawa-rawa baik rawa permanen maupun rawa musiman. Namun, beberapa permasalahan baik permasalahan internal maupun dari luar etnis itu sendiri perlu mendapat perhatian serius. Tingginya intensitas interaksi antara masyarakat Jawa yang begitu dekat dengan permukiman orang Marori dengan masyarakat Marori itu sendiri, misalnya, telah membawa perubahan pada pola hidup dan dampaknya yang telah dijelaskan di awal makalah ini. Masalah internal lain yang ada pada masyarakat adalah rendahnya pengetahuan tentang manfaat dan diversifikasi olahan sagu.

Apabila hutan sagu dapat dikelola dengan baik, maka pundi-pundi ekonomi masyarakat dapat bertumbuh dengan baik karena saat ini produk dari pohon sagu tidak hanya sebatas penyuplai bahan makanan tradisional tetapi dapat dikembangkan sebagai: sumber bioenergi berupa briket dan bioetanol dari limbah kulit batang dan ampas sagu (Risfaheri, 2016); gula cair dari pati sagu (Budiyanto et al., 2016); bahan bakar, biogas dan bahan kimia dari pati sagu (Prakoso, 2016); sediaan kosmetika dari tepung sagu (Darijanto, 2016); ampas sagu sebagai media tanam jamur (Suyerman dan Indrayana, 2016); dan aneka produk olahan makanan berbasis sagu (Herawati dan Sunarmani, 2016).

Keanekaragaman manfaat sagu merupakan sebuah peluang besar untuk memajukan kemandirian ekonomi masyarakat Marori tetapi ini harus dibarengi dengan setidak-tidaknya tiga hal berikut. Pertama, mesti ada upaya nyata untuk pemertahanan, perluasan hutan-hutan sagu, dan penerapan teknik-teknik budidaya sagu yang lebih modern sehingga sagu bisa sebagai sumberdaya atau bahan baku yang dapat menjamin usaha ekonomi yang keberlanjutan. Gambaran nilai ekonomi sagu dapat dilihat dari potensi produksi tepung sagu per hektar yang dapat dikonversikan ke dalam nilai uang. Ihalauw (2016) mengemukakan bahwa produksi sagu dapat mencapai 20 ton pati kering/hektar/tahun. Apabila harganya disimulasikan dengan harga pasar lokal di Merauke yang saat ini mencapai hingga Rp.12.000/kg (standar penjualan di pasar Rp300.000/karung $25 \mathrm{~kg}$ ), maka nilai ekonomi kotor (bruto) tepung sagu per hektar dapat mencapai Rp240juta.

Kedua, peningkatan ekonomi/usaha rakyat kecil dan kemampuannya untuk ikut usaha diversifikasi olahan sagu sehingga dapat meningkatkan nilai jualnya di pasar lokal maupun luar. Perlu dicatat dan diapresiasi usaha-usaha pemerintah daerah yang sudah memulai adanya kegiatan kearah ini bekerja sama dengan LSM, misalnya adanya pertemuan penyuluhan dan pelatihan ibu-ibu PKK untuk olahan sagu. Namun, pengalaman kami di lapangan menunjukkan bahwa pelatihan yang demikian mesti berkelanjutan dan dibarengi dengan pembimbingan lebih jauh; kalau tidak begitu, cenderung tidak ada tindak lanjut, dan keterampilan dan usaha kecil yang diharapkan tidak akan pernah terjadi.

Ketiga, walaupun nilai ekonomi di atas sangat menjanjikan untuk pengusahaan sagu dalam skala luas, ada masalah yang inheren secara budaya yang tidak mudah diatasi dalam waktu singkat. Ini terkait dengan keterikatan adat terhadap nilai sakral sagu itu dalam etnis Marori. Berdasarkan temuan kami selama penelitian, klen Mahuze tidak menghendaki adanya pemanfaatan sagu dalam skala luas dan tidak dapat diperjualbelikan ke pasar-pasar. Thobias 
Gebze, kepala Kampung Wasur (dalam wawancara pribadi, Januari 2016) mengatakan bahwa “...sagu... tidak (boleh) diperjualbelikan, pak, dia harus lewat hubungan saudara”. Artinya, seseorang yang ingin memberikan atau mendapatkan sagu, tidak boleh melalui jual beli, tetapi harus diberikan sebagai simbol persaudaraan. Pemanenan dan pengolahan sagu hanya dilakukan sewaktu-waktu untuk mencukupi kebutuhan di saat penyelenggaraan pesta atau ritual adat serta untuk kebutuhan konsumsi dalam rumah tangga. Hal ini merupakan salah satu tantangan jika sagu dimanfaatkan dalam skala luas sehingga pengembangan ekonomi berbasis sagu di masyarakat Marori sepatutnya dilakukan dengan pendekatan dialogis dengan masyarakat adat.

Pendekatan-pendekatan melalui adat diyakini dapat memecahkan kesenjangan antara pengetahuan lokal dan pengetahuan umum tentang manfaat (ekonomis) sagu yang lebih luas. Selain melalui pendekatan adat dan pemberdayaan masyarakat melalui program-program pelatihan dan pendampingan masyarakat dalam rangka diversifikasi olahan sagu, diharapkan lambat laun masyarakat menjadi semakin inovatif untuk ikut meningkatkan nilai tambah dan nilai jual sagu sehingga hambatan budaya seperti yang terjadi sekarang di Marori ini bisa diatasi, dan pada akhirnya sagu bisa benar-benar dapat dipakai untuk meningkatkan perekonomian masyarakat itu sendiri. Tampaknya, kendala adat ini tidak berlaku umum di etnisetnis lain di Merauke atau Papua, karena sagu memang bisa diperoleh di pasar-pasar Papua walaupun keberadaannya tidak sebanyak beras atau komoditi umum lainnya.

\section{KESIMPULAN}

Tanaman sagu bagi suku Marori sangat penting khususnya untuk kepentingan sosiokultural, tetapi pengetahuan lokal tentang sagu semakin terancam, seiring dengan semakin terancamnya bahasa dan budaya Marori. Ada faktor makro historis-eksternal berupa dominasi oleh etnis lain yang lebih kuat (dalam hal ini oleh etnis Marind) dan derasnya migrasi etnis luar Papua yang lebih kuat ke Merauke. Ini menyebabkan intensitas kontak bahasa-budaya dengan bahasabudaya yang jauh lebih dominan dan mendesak bahasa-budaya kecil minoritas seperti Marori. Kajian-kajian sosiolinguistik mengenai keterancaman bahasa-budaya menunjukkan bahwa kompleksitas variabel yang terlibat dalam ekologi bahasa-budaya dapat menimbulkan keterancaman ini, yang biasanya juga dibarengi oleh faktor-faktor mikro internal dari etnis itu sendiri, seperti faktor sikap (kebanggaan), kecelikan (literacy), dan sumber daya finansial dan manusia (Grenoble dan Whaley 2006, Arka 2013). Dalam segala aspek, diidentifiksasi dari sosiolinguistik, historis, agama, politik ke sosio-ekonomik dan demografis (Arka 2013), memang posisi Marori sangat tidak menguntungkan untuk vitalitas keberlangsungan hidupnya. Usaha untuk membantu membalikkan keadaan memang sangat berat, karena meliputi berbagai isu yang berhubungan dengan komunitas penuturnya, yang sesungguhnya terkait dengan pemberdayaan (capacity building), pembangkitan partisipasi aktif, pembentukan kemampuan kepemimpinan lokal yang baik, dan kemandirian finansial-ekonomi untuk bisa hidup di dunia modern. Semua ini meminta keterlibatan semua pemangku kepentingan, kerja sama yang erat dan berkelanjutan dengan etnis Marori sendiri. Untuk mencapai apa yang dikatakan tadi adalah sebuah tantangan ke depan yang tidak ringan, tetapi secara teoretis bukanlah hal yang mustahil, asalkan ada inisiatif konkret yang dilakukan.

Proyek dokumentasi yang dilaporkan dalam tulisan ini adalah salah satu inisiatif konkret ke arah itu, yang tujuannya adalah merekam berbagai pengetahuan etnobiologi lokal dan melakukan kajian-kajian yang hasilnya bisa bermanfaat secara praktis untuk masyarakat 
lokal, dan juga secara akademis-teoretis untuk memahamkan kepunahan bahasa-budaya. Temuan terkait dengan sagu yang disajikan dalam makalah ini hanyalah sebagian kecil saja dari temuan kami. Seperti yang telah disampaikan, dokumentasi seluk-beluk sagu dan kajian yang dipaparkan dalam makalah ini menunjukkan bahwa sagu sangat penting, dan dalam konteks Indonesia modern yang lebih luas, Merauke memiliki hutan sagu yang paling luas dan sangat potensial memiliki nilai ekonomis tinggi. Potensi ini merupakan peluang untuk memberdayakan ekonomi masyarakat lokal melalui sagu. Meskipun demikian, ada kendala untuk ekspansi pembudidayaan dalam skala besar karena ada pantangan adat-tradisional. Di luar dokumentasi tanaman sagu, ada berbagai wujud pengetahuan lokal yang terkait dengan tumbuhan flora maupun fauna, yang perlu didokumentasikan secara baik mengikuti prinsip-prinsip dokumentasi modern yang melibatkan rekaman audio-video yang nantinya bisa membentuk korpus lengkap, yang berguna untuk semua pihak baik masyarakat lokal biasa maupun masyarakat akademisi serta pemerintah lokal. Kemajuan proyek dokumentasi kami untuk bidang-bidang lain di luar sagu, bisa diakses lewat laman proyek kami di http://meraukelanguages.org/. Berbagai luaran dalam jangka panjang akan berupa buku acuan etnobiologi terkait dengan tumbuhan, reptil dan ikan yang ada di kawasan Taman Wasur. Selain itu juga ada buku-buku yang terkait dengan bahasa Marori seperti kamus dan buku ajar sederhana.

\section{CATATAN}

*Ucapan terimakasih disampaikan kepada ELDP London yang telah mendanai penelitian dokumentasi bahasa dan etnobiologi kami (MDP0336 2016-7), para narasumber di Kampung Wasur (di antaranya Pak Willem, Pak Thobias, Ibu Agustina Mbusa Gebze, dan Pak Lukas) dan di Tomeraw (di antaranya Pak Gideon Dimar dan Petrus Ndimar), yang telah meluangkan waktu dan tenaganya untuk memberikan data yang sebaik-baiknya. Makalah ini merupakan revisi dari makalah yang disajikan pada lokakarya internasional bahasa-bahasa Papua yang diadakan di Manokwari pada Januari 2017. Ucapan terima kasih juga disampaikan kepada peserta lokakarya yang telah memberikan masukannya untuk perbaikan makalah ini, di antaranya Nick Evans dan Bill Palmer.

\section{DAFTAR PUSTAKA}

Arka, I W. (2013). Language management and minority language maintenance in (eastern) Indonesia: Strategic issues. Language documentation and conservation No. 7, 74-105.

Avé, J. B. (1977). Sago in insular South-East Asia: historical aspects and contemporary use. Dalam Sago-76. Proc. 1st International Sago Symposium, Kuching (K. Tan ed.), Malaysia, 5-7 July, 1976, 21-30.

Balick, M. J. (1988). The palm tree of life. Advances in economic botany 6. New York: The New York Botanical Garden.

Boelaars, J. (1986). Manusia Irian: Dahulu-sekarang-dan masa depan. PT Gramedia, Jakarta.

Budiyanto, A. dan Richana, N. (2016). Gula cair dari pati sagu Sulawesi Tenggara. Makalah disampaikan pada Seminar dan Lokakarya Nasional Sagu 2016, Bogor, 9-10 November 2016.

Darijanto, S.T. (2016). Kemungkinan pemanfaatan sagu dalam sediaan kosmetika. Makalah disampaikan pada Seminar dan Lokakarya Nasional Sagu 2016, Bogor, 9-10 November 2016. 
Djoefrie, HMHB; Herodian, S.; Ngadiono, T.A. \& Amarillis, S. (2014). Sagu untuk kesejahteraan masyarakat Papua: Suatu kajian dalam upaya pengembangan sagu sebagai komoditas unggulan di provinsi Papua dan provinsi Papua Barat. Laporan penelitian. Jakarta: Unit Percepatan Pembangunan Provinsi Papua dan Provinsi Papua Barat.

Ellen, R. (2006). Local knowledge and management of sago palm (Metroxylon sagu Rottboell) Diversity in South Central Seram, Maluku, Eastern Indonesia. Journal of Ethnobiology, 26(2), 258-298.

Escalada, M. dan Heong, K. L. Ethnosciences techniques. https://www.yumpu.com/en/ document/view/45782097/tools-ethnoscience-techniques-ricehoppers/4. Diakses tanggal 3 Desember 2016.

Flach, Michiel. (1997). Sago palm (Metroxylon sagu Rottb.) Promoting the conservation and use of underutilized and neglected crops 13. Institute of Plant Genetics and Crop Plant Research, Gatersleben/International Plant Genetic Resources Institute, Rome, Italy.

Grenoble, L. A. and Whaley, L. J. (2006). Saving languages: An introduction to language revitalisation. Cambridge: Cambridge University Press.

Herawati, H. dan Sunarmani. (2016). Aneka produk olahan berbasis sagu. Makalah disampaikan pada Seminar dan Lokakarya Nasional Sagu 2016, Bogor, 9-10 November 2016.

Iskandar, J. (2012). Etnobiologi dan pembangunan berkelanjutan. AIPI, LPPM KPK Universitas Padjadjaran Bandung.

Prakoso, T. (2016). Potensi kebun/hutan sagu sebagai sumberdaya untuk pangan, bahan bakar dan produk kimia. Makalah disampaikan pada Seminar dan Lokakarya Nasional Sagu 2016, Bogor, 9-10 November 2016.

Risfaheri. (2016). Potensi sagu sebagai sumber bioenergi. Makalah disampaikan pada Seminar dan Lokakarya Nasional Sagu 2016, Bogor, 9-10 November 2016.

Suyerman, D. dan Indrayana, R. (2016). Pemanfaatan ampas sagu untuk media tanam jamur. Makalah disampaikan pada Seminar dan Lokakarya Nasional Sagu 2016, Bogor, 9-10 November 2016.

WWF. (2015). 1,2 juta hektar lahan Merauke untuk lumbung pangan nasional. www.wwf.or.id. Diakses tanggal 17 Januari 2017.

\footnotetext{
${ }^{1}$ Sar $=$ jeda waktu pemanfaatan sumber daya alam.

${ }^{2}$ Dema $=$ tokoh mistis dari zaman purbakala yang bersama makhluk lain menjadi bagian dunia ini dan kekuatannya beralih kepada manusia, hewan dan tumbuhan serta benda-benda yang sekarang membentuk alam dan masyarakat (Boelaars, 1986).
} 